\title{
PENGARUH KONFLIK KERJA DAN MOTIVASI KERJA TERHADAP KINERJA KARYAWAN
}

\author{
Shabrina Amirah Zafarina \\ Universitas Negeri Surabaya \\ shabrina.17080574081@mhs.unesa.ac.id \\ Agus Frianto \\ Universitas Negeri Surabaya \\ agusfrianto@unesa.ac.id
}

Abstract

This research aims to examine and analyze the impact of a work conflict and work motivation on employee performance. The research method is quantitative research. The sample in this study is 40 employees. The statistical analysis used in this study is the validity and reliability test, classical assumption test, and multiple linear tests. Data processing using SPSS software version 18. This study shows that work conflict has a negative and insignificant effect on employee performance and work motivation has a positive and significant effect on employee performance. This study implies that work conflicts that occur in employees in the company do not make the level of performance decrease; besides, the company has succeeded in implementing work motivation because the higher the motivation of employees, the higher the performance for the company.

Keywords: employee performance; work conflict; work motivation.

\section{PENDAHULUAN}

Saat ini perkembangan teknologi mencetuskan penemuan baru dalam menjalankan pekerjaan di beberapa bidang, contohnya di perusahaan manufaktur, perusahaan jasa, perbankan atau lainnya dan dengan adanya keadaan seperti ini menuntut adanya sumber daya manusia (SDM) yang inovatif, kreatif, dan berkompeten agar mampu bersaing dengan yang lainnya (Hidayat, 2018). SDM merupakan aset penting dari sebuah organisasi yang dituntut memiliki kualifikasi dan keahlian yang sesuai dengan kemampuan dan memiliki kinerja yang baik di lingkungan tempat kerja. Sedangkan sektor sumber daya merupakan salah satu kebutuhan dalam pola modern yang mengalami perubahan besar dalam hal pergantian bagian yang tidak terpakai di dalam perusahaan, SDM telah menjadi rencana yang strategis dalam sebuah organisasi (Jatobá et al., 2019).

Organisasi membutuhkan interaksi hubungan yang baik antara pemimpin dengan karyawan untuk meminimalisir konflik dalam bekerja. Konflik kerja seringkali terjadi seperti konflik antar individu, kelompok dan individu, serta antar kelompok dan kelompok lain (Anwari et al., 2016). Di sebuah organisasi, konflik dapat berimbas pada penurunan kinerja karyawan, dengan demikian hal tersebut dapat berimbas pada tujuan perusahaan menjadi tidak tercapai. Tetapi konflik juga memiliki dampak negatif dalam organisasi yaitu dapat menimbulkan pergesekan pada organisasi atau hubungan antar pribadi karyawan, menumbuhkan rasa ketidakpercayaan, menumbuhkan perasaan ingin selalu menang, dan dapat menimbulkan kesalahpahaman antar karyawan (Solatiah et al., 2019). Persaingan yang kurang baik berdasarkan ambisi, keinginan yang tinggi, serta tekad dan sikap emosional seseorang untuk mencapai kemenangan atau tujuan yang diinginkan merupakan bagian dari konflik. Selain itu, konflik dapat menyebabkan ketegangan, pertentangan, pertikaian dan mengakibatkan kekesalan yang berujung pada kekecewaan jika tidak dapat diselesaikan dengan baik. Konflik tidak bisa dihilangkan dan dihindari, namun bisa diminimalisir agar tidak mengarah pada perpecahan, perselisihan, pergesekan, dan pertentangan (Krisnawati \& Lestari, 2018). Konflik dapat mengakibatkan kerugian bagi organisasi/perusahaan yang disebabkan oleh menurunnya kinerja karyawan (Wati, 2017). 
Motivasi memiliki peranan penting karena dengan memiliki motivasi yang tinggi, karyawan akan melakukan pekerjaannya menjadi lebih antusias, lebih semangat, dan lebih efektif dalam bekerja. Dengan kata lain, jika karyawan termotivasi, kinerja mereka akan lebih unggul dan meningkat daripada mereka yang tidak memiliki motivasi dalam bekerja (Irawan et al., 2020). Motivasi merupakan pemberian daya penggerak yang menciptakan dorongan agar seseorang memiliki kemauan dan keinginan untuk melakukan pekerjaan secara bersama-sama, efektif dan efisien dalam bekerja, dan memaksimalkan segala upayanya guna mencapai tujuan dan kepuasan. Pemberian motivasi berawal dari suatu rangkaian yang bermula dari pemenuhan kebutuhan, timbul keinginan, lalu melakukan kegiatan dan tindakan yang akhirnya akan menghasilkan sebuah keputusan. Motivasi pada pegawai bisa dilakukan dengan berbagai cara, misalnya gaji maupun kompensasi yang sesuai dan setimpal dengan kapasitas dari pekerjaannya serta jaminan sosial karyawan berbentuk jaminan kesehatan yang bisa meningkatkan maupun mendorong semangat dalam bekerja. Motivasi kerja dan kinerja karyawan sangat berpengaruh bagi organisasi dalam pencapaian tujuan mereka (Puspitasari et al., 2020).

Berdasarkan hasil wawancara dengan staf Human Resource Department (HRD) dan staf administrasi, konflik kerja yang sering terjadi mengakibatkan menurunnya kinerja karyawan di CV Sumber Surya Jaya. Konflik kerja terjadi antar karyawana baik di workshop maupun kantor karena pegawai yang bekerja di perusahaan ini memiliki berbagai karakter dan sifat yang berbeda, seperti perbedaan usia, lingkungan, latar belakang, pendidikan, dan sifat-sifat lainnya yang mengakibatkan adanya perselisihan yang bisa muncul kapan saja bahkan setiap saat. Konflik kerja antar karyawan seperti kesalahpahaman dengan karyawan maupun dengan atasan, miss komunikasi dengan sesama rekan kerja atau dengan kuli proyek, kesalahan dalam pengerjaan barang, perbedaan persepsi, deadline proyek yang sudah di depan mata, pergesekan dan cekcok antar karyawan, serta emosi karyawan saat berada di lapangan atau proyek terjadi karena tuntutan pekerjaan untuk mencapai target yang sudah ditentukan. Selain itu, kinerja yang baik didapatkan salah satunya melalui motivasi kerja yang berpengaruh karyawan di CV Sumber Surya Jaya. Pemberian motivasi pada karyawan dengan sedemikian rupa dapat menunjang kinerja karyawan seperti kerjasama tim yang kompak antar karyawannya dalam meraih tujuan yang sama, rasa persaudaraan dan kedekatan hubungan antar karyawan yang erat, rasa aman dan nyaman di ruang lingkup kerja, pemberian reward berupa materi pada karyawan yang berprestasi, pemberian uang makan untuk setiap karyawannya yang digunakan untuk makan bersama-sama, dan jaminan kesehatan bagi semua karyawannya baik di kantor maupun di workshop.

Tujuan penelitian ini adalah untuk memahami pengaruh konflik kerja dan motivasi kerja pada kinerja karyawan.

\title{
KAJIAN PUSTAKA DAN PENGEMBANGAN HIPOTESIS
}

\begin{abstract}
Kinerja
Kinerja karyawan termasuk dalam salah satu faktor yang amat penting dan relevan untuk perusahaan, karena kinerja adalah pengaktualan perilaku kerja seseorang sebagai prestasi atau manifestasi dalam bekerja sesuai dengan tugas dan pekerjaan yang dilakukannya dalam sebuah perusahaan pada jangka waktu maupun periode tertentu (Putra, 2020). Kinerja adalah perolehan hasil dari usaha individu yang telah berpengalaman dan berbakat. Pencapaian tersebut tentu didukung oleh adanya kemampuan dan tindakan dalam keadaan maupun situasi tertentu. Tolok ukur seseorang dalam melaksanakan pekerjaan atau tugas dari perusahaaan merupakan bagian dari kinerja. Tingkat keberhasilan dan kemajuan usaha pada perusahaan sangat bergantung pada kinerja di mana karyawan mampu bekerja keras serta bertanggung jawab atas pekerjaan yang diberikan, memiliki rasa loyalitas tinggi, aktif dan cekatan, disiplin, serta berdedikasi tinggi terhadap tugas dan kewajiban pekerjaan yang dibebankan (Rudiantono, 2017). Kinerja karyawan yang maksimal dan optimal akan berdampak positif bagi perusahaan (Budiyanto \& Wikan, 2020).
\end{abstract}

Kinerja berawal dari kata job atau actual performance yang didefinisikan sebagai prestasi kerja yang aktual sebenarnya yang telah dicapai oleh individu (Fatikhin et al., 2017). Kinerja adalah hasil atau 
output dari pencapaian yang dilihat dari kualitas atau kuantitas dalam melakukan tugas dan pekerjaannya sesuai dengan tanggung jawab yang sudah dibebankan kepadanya (Polopadang et al., 2019). Tingkat keberhasilan individu secara menyeluruh selama periode tertentu tergantung dari hasil kinerjanya dalam melakukan tugas dan atau pekerjaannya dari beberapa kemungkinan yang ada seperti target, standar kerja, atau kriteria lainnya yang sudah disepakati dan ditetapkan bersama (Ginantra, 2017).

Indikator kinerja karyawan menurut Wahyudin \& Susilo (2020) dibagi menjadi enam bagian yang meliputi: (1) kualitas yaitu hasil yang dihitung dari pemahaman karyawan terhadap bobot pekerjaan yang diciptakan serta kemampuan dan keterampilan yang dimiliki dalam menyelesaikan pekerjaan; (2) kuantitas yaitu hasil kerja dari tingkat aktivitas yang dilihat dari jumlah kinerja yang dihasilkan atau diselesaikan dalam jangka waktu tertentu; (3) ketepatan waktu yaitu sebuah kegiatan yang telah dilakukan dari waktu awal pengerjaan sampai dengan output yang dihasilkan serta bisa meningkatkan waktu yang ada dalam melaksanakan kegiatan lain dan memenuhi target; (4) kerja sama yakni sebuah usaha yang dilakukan bersama antara kelompok maupun perorangan guna tercapainya tujuan bersama; (5) kemandirian sebagai sebuah tingkat di mana pegawai memiliki komitmen kerja atau tanggung jawab dalam menyelesaikan pekerjaanya; (6) inisiatif yaitu kompetensi dalam mengembangkan ide dan inovasi baru, menemukan peluang, serta cara baru dalam pemecahan suatu masalah dalam pekerjaan.

\section{Konflik Kerja}

Konflik dapat terjadi kapan ataupun di mana saja, misalnya konflik antar kelompok atau antar individu di sebuah organisasi. Perusahaan dituntut untuk mampu dan harus bisa membagi sumber dayanya yang terbatas sebab adanya perbedaan tujuan, status, nilai ataupun persepsi yang tidak sama. Sehingga, konflik tidak dapat dihindarkan, sebab konflik sebagai bagian dari pertentangan dan ketidaksesuaian yg terjadi baik antara dua orang maupun lebih dalam kelompok (Erwandari \& Sari, 2019). Menurut Erliana et al. (2020), konflik kerja ialah suatu perbedaan pendapat atau gagasan yang terjadi antara dua orang maupun lebih anggota di dalam organisasi kelompok yang diakibatkan oleh adanya perbedaan. Konflik merupakan perselisihan dan cara pandang yang berbeda tentang berbagai hal. Konflik pada organisasi dapat berdampak positif maupun negatif bagi organisasi dalam hal ini perusahaan. Konflik positif dapat menumbuhkan rasa semangat dalam bekerja, membuat penyelesaian pekerjaan cepat selesai dan meningkatkan tingkat kedisiplinan karyawan. Sedangkan konflik negatif dalam organisasi dalam hal ini perusahaan yaitu dapat menyebabkan menurunkan kepuasan kerja, stres kerja, menurunkan komitmen organisasi ataupun adanya niat untuk berhenti bekerja (Wenur et al., 2018).

Jenis-jenis konflik menurut Cendhikia et al. (2016) yaitu konflik intra individu, konflik antar kelompok dan individu, individu dan individu lain, konflik organisasi yang terjadi dalam kelompok yang sama, dan konflik intra perusahaan. Konflik dibagi menjadi dua yaitu: (1) functional conflict merupakan konflik yang memerkuat dalam mencapai tujuan kelompok dengan memberikan manfaat dan keuntungan; (2) disfuncional conflict merupakan konflik yang membatasi dalam mencapai tujuan kelompok serta dampaknya merugikan orang lain atau organisasi (Puspitasari et al., 2020).

Indikator konflik kerja menurut (Yofandi, 2017) dibagi menjadi dua kategori yang meliputi: (1) konflik fungsional merupakan yaitu bersaing dalam mendapatkan prestasi, tindakan menguntungkan menuju tujuan yang diharapkan, membangkitkan kreatifitas serta memunculkan ide atau inovasi, dan dorongan untuk melakukan perubahan; (2) konflik disfungsional yaitu tidak suka bekerja dalam kelompok, mendominasi diskusi, perselisihan antar individu dan kelompok, gesekan antar kepribadian, serta menimbulkan ketegangan.

\section{Motivasi Kerja}

Motivasi berawal dari kata movere artinya mendorong maupun menggerakkan. Motivasi yaitu gerakan atau dorongan yang kuat agar individu mau melakukan ataupun mengerahkan seluruh kompetensi dan ketrampilan yang dimilikinya untuk segera menyelesaikan tugas atau kegiatan yang 
dibebankan kepadanya dan menjadi tanggung jawab (Firdaus et al., 2017). Motivasi juga dapat didefinisikan sebagai awal proses aktivitas individu, yang diarahkan untuk mencapai tujuan tertentu untuk memenuhi kebutuhan (Omar et al., 2021). Pekerjaan yang dilakukan oleh pemimpin atau manajer yaitu memotivasi karyawannya dalam bentuk penyampaian ide dan inspirasi, pemberian semangat serta dukungan untuk mengambil keputusan tertentu (Erwatiningsih, 2017). Dari penjelasan di atas diketahui bahwa motivasi ialah dorongan yang membuat seseorang bergerak untuk mau melakukan pekerjaan yang diinginkan dengan sukarela tanpa ada unsur pemaksaan dari pihak lain. Sehingga, pekerjaan yang dilakukan bisa berjalan secara baik dan optimal serta dapat menciptakan sesuatu yang menguntungkan dan memuaskan (Wahyudi \& Tupti, 2019). Karyawan yang memiliki motivasi tinggi akan bekerja dengan penuh inisiatif, tanggung jawab dan disiplin serta efektif dalam melakukan pekerjaannya (Wuryani et al., 2021).

Faktor yang membuat karyawan mencapai kepuasan kerja sehingga dapat meningkatkan kinerjanya dan mencapai tujuan bagi perusahan yaitu motivasi kerja (Fadhil \& Mayowan, 2018). Motivasi kerja yang tinggi bisa memicu semangat, giat bekerja, dan intensitas penyelesaian tugas pekerjaan. Selain itu dengan adanya kompensasi atau imbalan yang sesuai berupa penghargaan pada karyawan serta upaya perusahaan untuk memenuhi kebutuhan karyawan berupa pemberian semangat dan dorongan. Untuk memeroleh hasil yang memuaskan karyawan harus memiliki semangat dalam bekerja karena perusahaan akan memberikan penghargaan yang sesuai dan sebanding dengan kinerjanya. Hal yang didapatkan karyawan bukan hanya imbalan berupa finansial (material) yang diterima, tetapi karyawan juga bisa mendapatkan promosi jabatan, peningkatan status pegawai dan kesempatan untuk memeroleh tingkat kesejahteraan pegawai (Rosyidah \& Kasnowo, 2018).

Indikator motivasi kerja menurut Fawaid \& Maufur (2018) yang menggunakan teori hierarki kebutuhan Maslow dibagi menjadi lima bagian yang meliputi: (1) kebutuhan fisiologis/fisik yang merupakan kebutuhan dasar manusia yang dapat berupa makanan, minuman, istirahat, kebutuhan biologis dan lain-lain; (2) kebutuhan keselamatan dan keamanan adalah kebutuhan seperti rasa aman dan keamanan selama bekerja, jaminan kesehatan, keamanan jaminan kerja, dan pensiun; (3) kebutuhan sosial adalah kebutuhan yang diterima oleh lingkungan sosial. contoh: kelompok kerja yang kompak, hubungan yang baik antara individu, dan persahabatan; (4) penghargaan/hargai kebutuhan yaitu kebutuhan tersebut berupa pencapaian kerja dan reward bagi karyawan yang berprestasi berupa pengakuan atas kemampuan dan keahlian yang dimiliki; (5) kebutuhan aktualisasi diri ini merupakan kebutuhan yang terletak pada penempatan individu di lingkungan serta pengembangan diri yang bisa berupa jenjang karir yang jelas, promosi jabatan bagi karyawan yang berprestasi atau melibatkan karyawan dalam berbagai aktivitas yang memiliki tantangan.

\section{Hubungan antar Variabel}

Berdasarkan penelitian Wahyudin \& Susilo (2020), variabel konflik kerja berpengaruh positif dan signifikan terhadap kinerja karyawan. Dalam penelitian yang dilakukan oleh Namora et al. (2020), secara parsial variabel konflik kerja berpengaruh positif dan signifikan pada kinerja karyawan. Sedangkan menurut Erwandari \& Sari (2019), terdapat pengaruh positif dan signifikan antara variabel konflik kerja dengan kinerja karyawan. Begitu pula dengan penelitian menurut Puspitasari et al. (2020), hasil analisis membuktikan bahwa konflik berpengaruh secara positif pada kinerja karyawan.

H1: Variabel konflik kerja berpengaruh positif dan signifikan pada kinerja karyawan.

Penelitian yang dilakukan oleh Nur et al. (2021) membuktikan bahwa variabel motivasi kerja berpengaruh secara positif pada kinerja karyawan. Begitu pula penelitian menurut Cendhikia et al. (2016), motivasi kerja karyawan memberi pengaruh positif pada kinerja karyawan. Lalu dalam penelitian Rosyidah \& Kasnowo (2018) menunjukkan variabel motivasi kerja terdapat pengaruh positif pada kinerja karyawan. Sedangkan menurut penelitian Harahap \& Tirtayasa (2020), secara parsial variabel motivasi kerja memberi pengaruh positif signifikan pada kinerja karyawan.

H2 : Variabel motivasi kerja berpengaruh positif dan signifikan pada kinerja karyawan. 


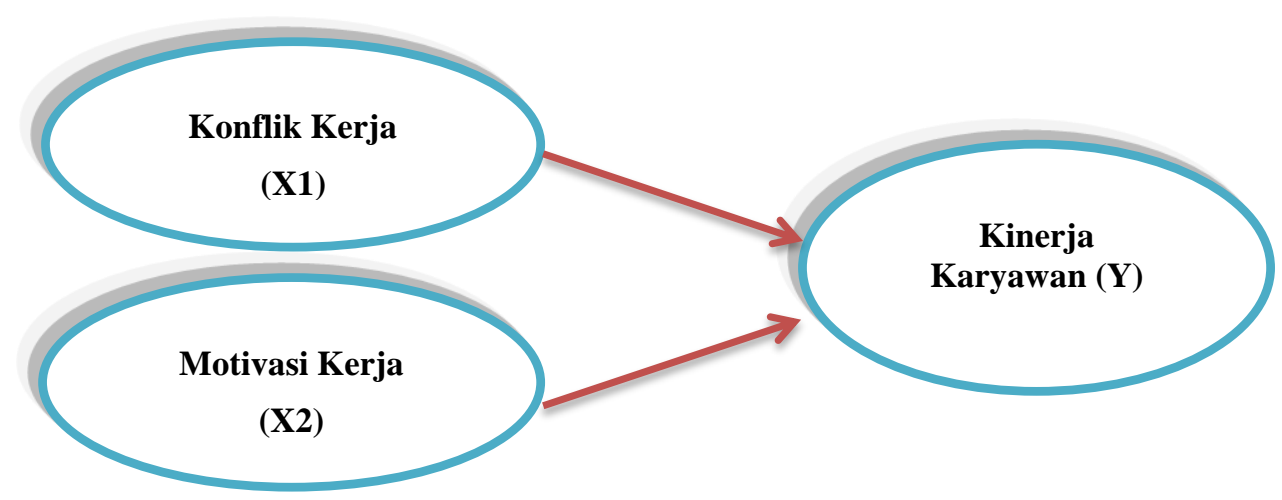

Gambar 1. KERANGKA KONSEPTUAL

\section{METODE PENELITIAN}

Jenis penelitian ini menggunakan pendekatan kuantitatif yaitu penelitian yang dilakukan secara acak dengan menggunakan intrumen penelitian analisis statistik untuk pengumpulan datanya. Data yang digunakan dalam penelitian ini yaitu data primer dan data sekunder. Data primer merupakan data yang dihasilkan dari sebar kuesioner online maupun yang dihasilkan secara langsung dari objek penelitian, dan data sekunder merupakan data yang di dapatkan dari sumber literasi sebagai pelengkapnya. Penelitian ini dilaksanakan di CV Sumber Surya Jaya, yang terletak di Jl Karah no.148, Kota Surabaya, Jawa Timur. Penelitian ini ini menggunakan teknik sampel jenuh yang seluruh karyawannya dijadikan sebagai sampel sebanyak 40 karyawan. Data dalam penelitian ini dikumpulkan dengan menggunakan metode pengamatan langsung, wawancara, serta angket yang dilakukan secara online. Skala pengukuran pada penelitian ini menggunakan skala Likert yang menjelaskan bahwa indikator variabel diuraikan untuk dijadikan sebagai acuan dalam menyusun butir-butir pernyataan di angket. Teknik analisis yang dipergunakan yakni uji regresi linier berganda dengan SPSS versi 18.

\section{HASIL DAN PEMBAHASAN}

\section{Uji Validitas}

Pengujian ini digunakan guna melihat apakah sebuah alat ukur sudah melaksanakan fungsi ukurnya. Validitas memerlihatkan akurasi ataupun ketepatan instrumen pengukuran dalam menjalankan fungsi ukurnya dan digunakan dalam menguji apakah pernyataan dalam kuesioner tersebut layak dengan melihat perbandingan $r$ hitung dan $r$ tabel, sehingga dapat menjelaskan isi yang akan diukur dengan menggunakan kuesioner. Data dianggap valid bila $r$ hitung $>r$ tabel.

Berdasarkan Tabel 1, pengujian validitas disebar kepada $n=32$ responden dan $r$ hitung $(0,349)$ yang diperoleh dari tabel distribusi mendapatkan hasil bahwa 10 pernyataan variabel X1 konflik kerja valid, 10 pernyataan variabel X2 motivasi kerja valid, dan 15 pernyataan variabel $\mathrm{Y}$ kinerja karyawan valid yang dibuktikan dengan hasil $>\mathrm{r}$ tabel.

\section{Uji Reliabilitas}

Uji reliabilitas membuktikan pada tingkat keandalan dari sebuah indikator yang dipergunakan pada penelitian yang bertujuan untuk menguji dan memastikan apakah angket penelitian yang akan dipergunakan pada pengumpulan data penelitian bersifat andal maupun tidak. Angket dianggap andal apabila angket tersebut diukur kembali, maka akan memeroleh hasil yang sama. Hasil pengujian ini bisa diketahui dari nilai Cronbach's Alpha. Apabila skor tersebut > 0,70 maka semua item dapat digunakan sebagai alat ukur atau bisa dikatakan konsisten. Hasil pengujian ini membuktikan skor Cronbach's Alpha senilai 0,861 >0,70, maka data tersebut merupakan data yang bersifat reliabel. 
Shabrina Amirah Zafarina \& Agus Frianto. Pengaruh Konflik Kerja dan Motivasi Kerja terhadap Kinerja Karyawan

Tabel 1.

HASIL UJI VALIDITAS

\begin{tabular}{cccc}
\hline Variabel & Kode Butir Pernyataan & Nilai r hitung & Hasil \\
\hline Variabel X1 (Konflik Kerja) & X1.1 & 0,687 & valid \\
& X1.2 & 0,770 & valid \\
& X1.3 & 0,750 & valid \\
& X1.4 & 0,615 & valid \\
& X1.5 & 0,679 & valid \\
& X1.6 & 0,848 & valid \\
& X1.7 & 0,763 & valid \\
& X1.8 & 0,663 & valid \\
& X1.9 & 0,747 & valid \\
Variabel X2 (Motivasi Kerja) & X2.1 & 0,684 & valid \\
& X2.2 & 0,548 & valid \\
& X2.3 & 0,427 & valid \\
& X2.4 & 0,609 & valid \\
& X2.5 & 0,435 & valid \\
& X2.6 & 0,709 & valid \\
& X2.7 & 0,488 & valid \\
V2.8 & 0,615 & valid \\
& X2.9 & 0,626 & valid \\
& X2.10 & 0,361 & valid \\
& Y1 & 0,501 & valid \\
& Y2 & 0,422 & valid \\
& Y3 & 0,486 & valid \\
& Y4 & 0,678 & valid \\
Y5 & 0,570 & valid \\
& Y6 & 0,466 & valid \\
Y7 & 0,511 & valid \\
& Y8 & 0,612 & valid \\
Y9 & 0,594 & valid \\
& Y10 & 0,625 & valid \\
& Y11 & 0,500 & valid \\
& Y12 & 0,593 & valid \\
& Y14 & 0,580 & valid \\
& Y15 & 0,376 & valid \\
& 0,653 & valid \\
& 0,436 & valid \\
\hline Sinerja Karyawan) & &
\end{tabular}

Sumber: Output SPSS 18 (2021, data diolah)

\section{Uji Asumsi Klasik}

Pengujian yang dipergunakan pada penelitian ini di bagi menjadi 4 uji yakni uji heterokedastisitas, multikolinieritas, normalitas, dan uji autokorelasi. Uji normalitas dipergunakan dalam mengkuji apakah pada model regresi yang berupa variabel dependen ataupun variabel independen memunyai distribusi normal maupun tidak normal. Data dapat dikatakan normal apabila tingkat signifikasinya sebesar >0,05 pada $(\mathrm{P}>0,05)$. Sebaliknya, bila angka Sig. $<0,05$ pada $(\mathrm{P}<0,05)$, data tersebut tidak normal. Tabel 2 menunjukkan hasil uji normalitas dengan mengunakan metode Kolmogorov-smirnov (KS) dihasilkan skor Asymp. Sig. (2-tailed) senilai 0,544 > dari 0,05. Hal demikian berarti data memunyai distribusi normal. Uji multikolinearitas tujuannya guna mengkuji apakah pada model regresi ada hubungan di antara variabel independen. Model regresi yang baik harusnya tidak ditemukan hubungan antar variabel bebas. Apabila skor VIF $<10$ dan tolerance value $>0,1$ multikolinieritas tidak terjadi. Tabel 2 menunjukkan bahwa skor VIF variabel X1 dan X2 yaitu 1,081 $<10$ atau skor tolerance value senilai $0,925>0,1$ maka data tersebut tidak mengalami multikolinieritas. Uji Heteroskedastisitas tujuannya guna melihat apakah pada model regresi mengalami ketidaknyamanan variasi dari residiual pengamatan satu ke pengamatan lainnya. Bila variasi residiual dari sebuah pengamatan lainnya tetap maka disebut terjadi homokedastisitas, atau apabila variasi tidak sama maka dapat dianggap terjadi heteroskedastisitas. Hasil output Scatterplots 
pada Gambar 2 menunjukkan titik-titik data tidak berkumpul pada satu area, melainkan menyebar di sekitar angka 0, serta tidak terbentuk sebuah pola. Hal tersebut berarti bahwa tidak terdapat heteroskedastitas pada data yang diuji. Terakhir, yaitu Uji Autokorelasi dengan bantuan DurbinWatson (DW) memeroleh hasil nilai sebesar $\mathrm{d}=1,929$ dengan tingkat derajat kepercayaan 5\% (0.05), total variabel bebas $(\mathrm{k})=2$, dan total responden $(\mathrm{n})=40$ yang disubstitusikan ke dalam persamaan $\mathrm{dU}<\mathrm{d}<4$-dU menjadi 1,6000 < 1,929 < 2,4000. Artinya, tidak ditemukan adanya autokorelasi.

Tabel 2.

\section{UJI ASUMSI KLASIK}

\begin{tabular}{|c|c|c|c|c|}
\hline \multirow{2}{*}{ Variabel } & \multirow{2}{*}{$\begin{array}{c}\text { Normalitas } \\
\text { Sig. }\end{array}$} & \multirow{2}{*}{$\begin{array}{c}\text { Autokorelasi } \\
D W\end{array}$} & \multicolumn{2}{|c|}{ Multikolinieritas } \\
\hline & & & Tolerance & VIF \\
\hline & ,544 & 1,929 & & \\
\hline Konflik Kerja & & & ,925 & 1,081 \\
\hline Motivasi Kerja & & & ,925 & 1,081 \\
\hline
\end{tabular}

Sumber: Output SPSS 18 (2021, data diolah)

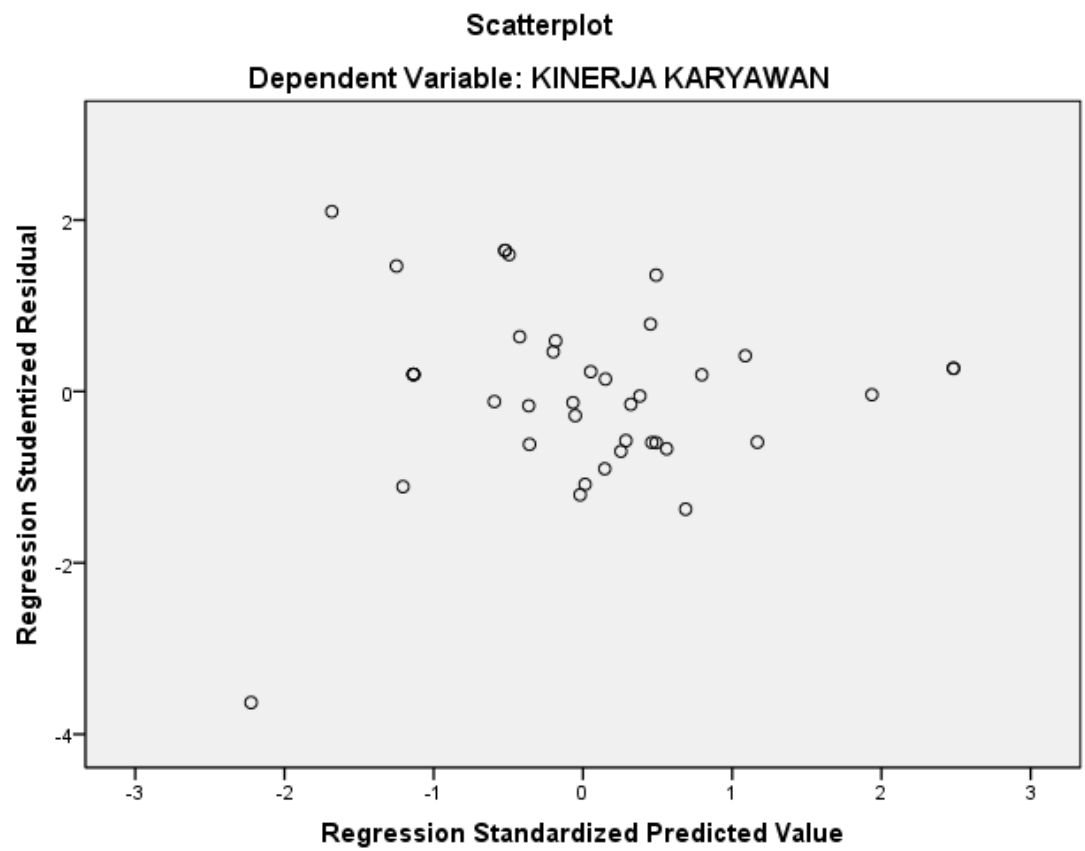

Sumber: Output SPSS 18 (2021, data diolah)

\section{Gambar 2. OUTPUT SCATTERPLOT}

\section{Uji Hipotesis}

Uji hipotesis merupakan pengujian guna melakukan pembuktian apakah hipotesis yang dibuat penulis berpengaruh atau tidak. Dilakukan menggunakan uji koefesien determinasi $\left(\mathrm{R}^{2}\right)$ yang berguna untuk melihat ukuran daya variabel independen saat menguraikan variasi dari variabel dependen. Dari hasil uji determinasi $\left(\mathrm{R}^{2}\right)$ diketahui skor Adjusted $R$ square senilai $0,428(42,8 \%)$. Hal ini berarti bahwa secara gabungan variabel konflik kerja ataupun motivasi kerja dapat menjelaskan sebesar $42,8 \%$ variasi variabel kinerja karyawan di perusahaan. Adapun nilai sisanya senilai 57,2 (100\% - 42,8\%) dijelaskan oleh faktor variabel lain di luar dari model ini.

Hasil uji regresi linear berganda dapat dilihat dengan menggunakan persamaan regresi (1).

Kinerja Karyawan $=28,299+(-0,188) \mathrm{X} 1+0,969 \mathrm{X} 2+e$ 
Shabrina Amirah Zafarina \& Agus Frianto. Pengaruh Konflik Kerja dan Motivasi Kerja terhadap Kinerja Karyawan

Dari persamaan di atas dapat di uraikan bahwa pengaruh variabel X1 dan X2 menunjukkan nilai konstanta senilai 28,299. Jika X1 dan X2 nilainya 0, maka variabel Y memunyai skor senilai 28,299. Koefisien regresi untuk variabel konflik kerja (X1) senilai $-0,188$ adalah bila variabel bebas lain skor nya tetap dan X1 naik senilai $1 \%$, maka Y juga akan naik senilai 0,188 . Koefisien yang nilainya negatif berarti yaitu tidak terdapat korelasi antara konflik kerja pada kinerja karyawan. Begitu pula dengan koefisien regresi untuk variabel X2 senilai 0,969 maknanya adalah apabila variabel bebas lain skor nya tetap atau X2 naik senilai $1 \%$, maka Y akan naik senilai 0,969 . Koefisien yang nilainya positif yaitu ditemukan korelasi positif antara motivasi kerja pada kinerja karyawan.

Uji t merupakan pengujian guna melihat bagaimana pengaruh setiap variabel independen yang meliputi X1 atau X2 secara sendiri-sendiri pada pengaruh variabel dependen yakni kinerja (Y) secara parsial. Pengujian ini bisa dilakukan melalui perbandingan $t$ hitung dan $t$ tabel ataupun bisa dilihat pada kolom signifikansi t tabel di Tabel 3.

Hasil uji t menjelaskan bahwa variabel konflik kerja (X1) tidak berpengaruh pada kinerja karyawan di CV Sumber Surya Jaya. Hal tersebut terbukti dari hasil secara parsial pengaruh variabel X1 terhadap $\mathrm{Y}$ diketahui nilai signifikansinya senilai $0,377>0.05$ dan skor $\mathrm{t}$ hitung $-0,893<\mathrm{t}$ tabel 2,026. Begitu pula dengan hasil dari uji $\mathrm{T}$ dari variabel motivasi kerja (X2) terdapat pengaruh motivasi kerja pada kinerja karyawan di CV Sumber Surya Jaya. Hal tersebut dibuktikan dengan secara parsial pengaruh variabel X2 terhadap Y di diketahui nilai signifikansinya senilai $0,000<0,05$ dan skor $\mathrm{t}$ hitung 4,738 $<\mathrm{t}$ tabel 2,026.

Tabel 3.

HASIL UJI REGRESI LINIER BERGANDA

\begin{tabular}{|c|c|c|c|c|}
\hline \multirow{2}{*}{ Variabel } & \multirow{2}{*}{$\begin{array}{c}\text { Determinasi }\left(\mathbf{R}^{2}\right) \\
\text { Adj. } R \text { Square }\end{array}$} & \multirow{2}{*}{$\begin{array}{c}\text { Coefficient } \\
\text { B } \\
\end{array}$} & \multicolumn{2}{|c|}{ Uji t } \\
\hline & & & $t$ & Sig. \\
\hline & 428 & & & \\
\hline (Constant) & & 28,299 & 2,712 & ,010 \\
\hline Konflik Kerja & &,- 188 &,- 893 & 377 \\
\hline Motivasi Kerja & & ,969 & 4,738 & 000 \\
\hline
\end{tabular}

Sumber : Output SPSS 18 (2021,data diolah)

\section{Pengaruh Konflik Kerja terhadap Kinerja}

Variabel konflik kerja (X1) secara parsial berpengaruh tidak signifikan terhadap kinerja (Y) di CV Sumber Surya Jaya. Maka, H1 ditolak dan tidak dapat dibuktikan. Hal tersebut selaras dengan penelitian dari Wati (2017) yang memaparkan bahwa Konflik tidak bisa dihilangkan dan dihindari, namun bisa diminimalisir. Konflik dapat menyebabkan ketegangan, pertentangan, pertikaian, dan mengakibatkan kekesalan jika tidak dapat diselesaikan dengan baik yang dapat mengakibatkan kerugian bagi perusahaan yang disebabkan oleh menurunnya kinerja karyawan. Terjadinya konflik kerja di perusahaan berasal dari berbagai sebab di antaranya kesalahan komunikasi yang buruk, kurang jelasnya struktur pekerjaan yang diberikan, masalah individu yang terjadi dalam diri maupun kelompok. Tetapi, suatu perusahaan bisa mendapatkan keuntungan yang tinggi seperti terciptanya persaingan yang sehat antar individu maupun kelompok jika konflik kerja dapat di atasi dengan baik dan benar. Begitu juga dengan penelitian menurut Erliana et al. (2020) menjelaskan bahwa suatu konflik yang terjadi di perusahaan memang seringkali timbul, tetapi konflik harus segera diminimalisir dengan cara menciptakan iklim atau suasana kerja yang baik, terdapatnya koordinasi dan situasi kondusif sehingga dapat meredam konflik yang terjadi dalam organisasi.

Hasil observasi maupun wawancara yang sudah dilakukan di CV Sumber Surya Jaya, Surabaya menunjukkan bahwa variabel konflik kerja tidak memengaruhi kinerja karyawan didalam penyelesaian pekerjaan. Artinya, seiring dengan konflik kerja yang ada di perusahaan tidak membuat karyawan merasa terganggu dan menjadi halangan karena konflik merupakan hal yang lumrah terjadi baik perselisihan antar karyawan, perbedaaan pendapat, maupun kesalahan komunikasi dari atasan ke bawahan. Namun, hal tersebut tidak mengurangi kinerja mereka saat bekerja maupun aktivitas untuk 
menyelesaikan pekerjaan karena sudah menjadi tanggung jawab masing-masing karyawan untuk memaksimalkan kinerjanya.

\section{Pengaruh Motivasi Kerja terhadap Kinerja}

Variabel motivasi kerja (X2) secara parsial berpengaruh positif dan signifikan terhadap Kinerja (Y) di CV Sumber Surya Jaya. Maka, H2 diterima dan dapat dibuktikan. Hal tersebut selaras dengan penelitian oleh Harahap \& Tirtayasa (2020) yang menyatakan motivasi kerja merupakan faktor yang mendukung dalam memertahankan kinerja karyawan di perusahaan. Karena,dengan memiliki motivasi kerja yg tinggi maka kinerja tenaga kerja juga akan semakin tinggi. Motivasi kerja yang diberikan misalnya dapat berupa pendidikan pada karyawan, pelatihan kerja, atau workshop yang dapat meningkatkan kinerja pada karyawan. Begitu pula dengan penelitian menurut Setiawan \& Indahingwati, (2018) kemampuan, kreatifitas, dan kecakapan yang dimiliki oleh karyawan tidak akan ada artinya jika tidak diikuti dengan motivasi yang tinggi. Motivasi yang diberikan misalnya berupa gaji, insentif, bonus, upah dan asuransi. Jika semua hal ini telah dilakukan oleh perusahaan kepada karyawan, kinerja karyawan juga akan meningkat.

Dari hasil observasi maupun wawancara yang sudah dilakukan di CV Sumber Surya Jaya, Surabaya membuktikan bahwa variabel motivasi kerja memberi pengaruh positif dan signifikan pada kinerja karyawan di CV Sumber Surya Jaya. Perusahaan berhasil dalam mengimplementasikan motivasi kerja seperti kerjasama tim yang kompak antar karyawannya dalam meraih tujuan yang sama, rasa persaudaraan dan kedekatan hubungan antar karyawan yang erat, rasa aman dan nyaman saat berada di ruang lingkup kerja, pemberian reward berupa materi pada karyawan yang berprestasi maupun dorongan dari faktor-faktor lainnya kepada karyawan untuk meningkatkan kinerjanya.

\section{KESIMPULAN}

Konflik kerja (X1) tidak berpengaruh signifikan pada kinerja karyawan (Y) di CV Sumber Surya Jaya. Hal tersebut artinya bahwa walaupun konflik kerja tidak bisa dihindari tetapi dapat diminimalisir dan tidak berpengaruh kinerja karyawan di perusahaan. Motivasi kerja (X2) memberi pengaruh positif signifikan pada kinerja karyawan (Y) di CV Sumber Surya Jaya. Hal ini berarti bahwa motivasi kerja yang diberikan pada pegawai bertambah maka kinerja dari pegawai pada perusahaan juga akan tinggi dan bertambah. Dengan adanya penelitian terkait pengaruh konflik kerja dan motivasi kerja terhadap kinerja karyawan di CV Sumber Surya Jaya diharapkan dapat menjadi acuan dan menjadi masukan dalam membuat pertimbangan maupun pengambilan keputusan yang berkaitan dengan konflik kerja dan motivasi kerja di CV Sumber Surya Jaya. Penelitian selanjutnya diharapkan dapat melibatkan variabel kepuasan kerja dan stres kerja terhadap kinerja karyawan.

\section{DAFTAR PUSTAKA}

Anwari, M. R., Sunuharyo, B. S., \& Ruhana, I. (2016). Pengaruh Konflik Kerja ddan Stres Kerja Terhadap Karyawan (Studi pada Karyawan PT Telkomsel Branch Malang). Jurnal Administrasi Bisnis, 41(1), 1-10.

Budiyanto, A., \& Wikan, Y. (2020). Pengaruh Disiplin Kerja, Motivasi, Stres Kerja dan Pengembangan Karier terhadap Kinerja Karyawan pada Pt. Kelola Jasa Artha. ESENSI: Jurnal Manajemen Bisnis, Vol. 23 No. 3 / 2020, 23(3), 225-246.

Cendhikia, D., Utami, H., \& Prasetya, A. (2016). Pengaruh Konflik Kerja dan Stres Kerja terhadap Motivasi Kerja Karyawan dan Kinerja Karyawan (Studi pada karyawan PT.Telekomunikasi Indonesia, Tbk Witel Jatim Selatan). Jurnal Administrasi Bisnis S1 Universitas Brawijaya, 35(2), 136-145.

Erliana, Zamora, R., \& Hadi, M. A. (2020). Pengaruh Stres Kerja, Konflik Kerja dan Kepuasan Kerja terhadap Kinerja Karyawan pada Pt. Delimax Konstruksi Indonesia Batam. Jurnal BENING 
Shabrina Amirah Zafarina \& Agus Frianto. Pengaruh Konflik Kerja dan Motivasi Kerja terhadap Kinerja Karyawan

Prodi Manajemen Universitas Riau Kepulauan Batam, 7(1), 17-30.

Erwandari, E. P., \& Sari, A. P. (2019). Pengaruh Konflik Kerja dan Stres Kerja terhadap Kinerja Karyawan PT Pos Indonesia (Persero) Bengkulu 38000. Managament Insight: Jurnal Ilmiah Manajemen, 13(2), 39-49. https://doi.org/10.33369/insight.13.2.39-49

Erwatiningsih, E. (2017). Pengaruh Motivasi, Komunikasi dan Budaya Organisasi terhadap Kinerja Karyawan. Jurnal Sosial Humaniora, 8(1), 132-138. https://doi.org/10.30997/jsh.v8i1.701

Fadhil, A., \& Mayowan, Y. (2018). Pengaruh Motivasi Kerja dan Kepuasan Kerja terhadap Kinerja Karyawan AJB Bumiputera. Jurnal Administrasi Bisnis, 54(1), 40-47. http://administrasibisnis.studentjournal.ub.ac.id/index.php/jab/article/view/2215

Fatikhin, F., Hamid, D., \& Mukzam, M. (2017). Pengaruh Konflik Kerja dan Stres Kerja terhadap Kinerja Karyawan (Studi pada karyawan PT. Bank Rakyat Indonesia (Persero) Cabang Soekarno Hatta Malang). Jurnal Administrasi Bisnis S1 Universitas Brawijaya, 47(1), 172-180.

Fawaid, A., \& Maufur. (2018). Motivation and Personality (Motivasi dan Kepribadian). Yogyakarta: Cantrik Pustaka.

Firdaus, Widyanti, R., \& Khuzaini. (2017). Pengaruh Motivasi dan Lingkungan Kerja terhadap Kinerja Karyawan. Jurnal Komunikasi, Bisnis, Dan Manajemen, 4(1), 86-98.

Ginantra, I. P. G. (2017). Pengaruh Kepemimpinan, Motivasi dan Kepuasan Kerja terhadap Kinerja Karyawan PT Jasamarga Bali Tol di Denpasar. JAGADHITA: Jurnal Ekonomi \& Bisnis, 4(2), 101-115. https://doi.org/10.22225/jj.4.2.309.101

Harahap, S. F., \& Tirtayasa, S. (2020). Pengaruh Motivasi, Disiplin, dan Kepuasan Kerja terhadap Kinerja Karyawan Di PT. Angkasa Pura II (Persero) Kantor Cabang Kualanamu. Maneggio: $\begin{array}{llll}\text { Jurnal Ilmiah Magister } \quad \text { Manajemen, } & \text { 3(1), }\end{array}$ https://doi.org/10.30596/maneggio.v3i1.4866

Hidayat, M. (2018). SDM yang Kreatif, Inovatif, dan Produktif. Dkjn.Kemenkeu.Go.Id. (https://www.djkn.kemenkeu.go.id/kanwil-jateng/baca-artikel/12739/SDM-yang-KreatifInovatif-dan-Produktif.html, Diakses pada tanggal 16 April 2021)

Irawan, D. A., Marsherina, H., Evasari, J., \& Marceline (2020). Employee Performance: The Effect of Work Motivation, Work Discipline, and Job Satisfaction at one of music companies in Indonesia. Journal of Research in Business, Economics, and Education, 2(4), 710-719. http://ejournal.stie-kusumanegara.ac.id/index.php/jrbee/article/view/95

Jatobá, M., Santos, J., Gutierriz, I., Moscon, D., Fernandes, P. O., \& Teixeira, J. P. (2019). Evolution of Artificial Intelligence Research in Human Resources. Procedia Computer Science, 164, 137142. https://doi.org/10.1016/j.procs.2019.12.165

Krisnawati, S., \& Lestari, Y. T. (2018). Stres Kerja dan Konflik Kerja Pengaruhnya terhadap Kinerja Karyawan. Jurnal Riset Manajemen Dan Bisnis (JRMB) Fakultas Ekonomi UNIAT, 3, 285-292.

Lestari, W. M., Liana, L., \& Aquinia, A. (2020). Pengaruh Stres Kerja, Konflik Kerja dan Beban Kerja terhadap Kinerja Karyawan. Bisnis Dan Ekonomi, 27(2), 100-110.

Namora, Windy, Sharon, \& Stephani. (2020). Pengaruh Disiplin, Konflik Kerja dan Stres Kerja terhadap Kinerja Karyawan pada PT. Sukses Usaha Nirwana. Jurnal Manajemen Bisnis Eka Prasetya : Penelitian Ilmu Manajemen, 6(2), 76-88. https://doi.org/10.47663/jmbep.v6i2.65 
Nur, M. M. F., Mane, A. A., \& Nur, I. (2021). Analisis Pengaruh Gaya Kepemimpinan dan Motivasi Kerja terhadap Kinerja Karyawan pada PT Berita Kota Makassar. Economic Bosowa Journal, $7(001), 225-236$.

Omar, M. S., Mohd Idrus, I., \& Jamal, N. A. (2021). The Influence of Job Motivation on Job Satisfaction: A Case Study of Polytechnic Academic Staff. Malaysian Journal of Social Sciences and Humanities (MJSSH), 6(1), 206-213. https://doi.org/10.47405/mjssh.v6i1.624

Polopadang, K. Y., Tewal, B., \& Walangitan, M. D. (2019). Dampak Konflik dan Stress Kerja terhadap Kepuasan Kerja dan Kinerja Karyawan PT. Tirta Investama (DANONE) Aqua Airmadidi. Jurnal EMBA: Jurnal Riset Ekonomi, Manajemen, Bisnis Dan Akuntansi, 7(4), $5215-5224$.

Puspitasari, A., Adjie, S., \& Chamidah, S. (2020). Pengaruh Konflik Kerja, Stres Kerja, dan Motivasi Kerja terhadap Kinerja Karyawan pada Maju Hardware Madiun. ASSET: Jurnal Manajemen Dan Bisnis, 1(1), 27-34. https://doi.org/10.24269/asset.v1i1.2555

Putra, E. (2020). Pengaruh Konflik Kerja dan Stres Kerja terhadap Kinerja Karyawan pada CV. Apotik Keluarga Pekanbaru. Eko Dan Bisnis: Riau Economic and Business Review, 11(3), 268277. https://doi.org/10.36975/jeb.v11i3.285

Rosyidah, E., \& Kasnowo. (2018). Pengaruh Lingkungan Kerja, Konflik dan Motivasi terhadap Kinerja Karyawan CV. Mitra Kemas Paperindo. Bisman (Bisnis \& Manajemen): The Journal Of Business And Management, 1(1), 1-14.

Rudiantono, Y. (2017). The Influence of Motivation and Work Environment on The Performance of Employees. Sinergi: Jurnal Ilmiah Ilmu Manajemen, 6(2), 54-61. https://doi.org/10.25139/sng.v6i2.80

Setiawan, M. A., \& Indahingwati, A. (2018). Pengaruh Kompensasi, Motivasi dan Lingkungan Kerja terhadap Kinerja Karyawan pada PT FIF Surabaya. Jurnal Ilmu Dan Riset Manajemen Sekolah Tinggi Ilmu Ekonomi Indonesia (STIESIA) Surabaya, 7(10), 1-13.

Solatiah, Siti, N., \& Muhammad, F. L. (2019). The Effect of Burnout, Leadership Style and Work Conflict on Civil Servants' Performance in Sub-Districts Throughout The City of Mataram, Indonesia. Eurasia: Economics \& Business, 6(24), June 2019, 11(1), 1-14.

Sugiyono. (2018). Metode Penelitian Kuantitatif. Bandung: Alfabeta.

Wahyudi, W. D., \& Tupti, Z. (2019). Pengaruh Budaya Organisasi, Motivasi dan Kepuasan Kerja Terhadap Kinerja. Maneggio: Jurnal Ilmiah Magister Manajemen, 2(1), 31-44. https://doi.org/10.30596/maneggio.v2i1.3363

Wahyudin, \& Susilo, Y. H. (2020). Pengaruh Konflik Kerja dan Stres Kerja terhadap Kinerja Karyawan. Journal EKOMABIS LPPM Pelita Bangsa, 01(01), 45-58. https://doi.org/https://doi.org/10.37366/ekomabis.v1i01.5

Wati, R. (2017). Pengaruh Konflik Kerja, Kepemimpinan, Motivasi Kerja terhadap Kinerja Karyawan Departemen Sewing (Studi Empiris pada PT Liebra Permana di Bawen Kabupaten Semarang). Journal of Chemical Information and Modeling, 53(9), 1689-1699.

Wenur, G., Sepang, J., \& Dotulong, L. (2018). Pengaruh Konflik Kerja Dan Stres Kerja Terhadap Kinerja Karyawan Pada Pt. Bank Negara Indonesia (Persero) Tbk Cabang Manado. Jurnal EMBA: Jurnal Riset Ekonomi, Manajemen, Bisnis Dan Akuntansi, 6(1), 51-60. https://doi.org/10.35794/emba.v6i1.18760 
Shabrina Amirah Zafarina \& Agus Frianto. Pengaruh Konflik Kerja dan Motivasi Kerja terhadap Kinerja Karyawan

Wuryani, E., Rodli, A. F., Sutarsi, S., Dewi, N. N., \& Arif, D. (2021). Analysis of Decision Support System on Situational Leadership Styles on Work Motivation and Employee Performance. Management Science Letters, 11, 365-372. https://doi.org/10.5267/j.msl.2020.9.033

Yofandi, A. (2017). Pengaruh Konflik Kerja, Stres Kerja, dan Semangat Kerja terhadap Kinerja Karyawan pada PT. Perkebunan Nusantara V (Persero) Pekanbaru. JOM Fekon, 4(1), 10151029. 